\title{
Pengaruh Biostimulan, Asam Humat, Mikoriza dan Kombinasi Dosis Pemupukan Terhadap Pertumbuhan Tebu (Saccharum officinarum 1.) dan Produksi Tebu Pada Tanah Eutropepts Pasuruan
}

\author{
The Effect of Biostimulant, Humic Acid, Mychorrizae, and Inorganic \\ Fertilizer Dosage on Sugarcane (Saccharum officinarum) Growth and \\ Sugarcane Yield on Eutropepts Soil at Pasuruan Area
}

\author{
Arinta Rury Puspitasari ${ }^{1)}$ dan Aris Lukito ${ }^{1)}$ \\ 1) Pusat Penelitian Perkebunan Gula Indonesia \\ Alamat korespondensi, Email: arintaruryp@gmail.com
}

\begin{abstract}
ABSTRAK
Peningkatan produktivitas tebu perlu diupayakan untuk mencapai swasembada gula. Salah satu cara yang dapat dilakukan adalah penggunaan biostimulan, mikoriza serta asam humat. Pemberian biostimulan, asam humat dan mikoriza diharapkan dapat mengurangi penggunaan pupuk anorganik. Tujuan penelitian adalah mendapatkan perlakuan terbaik dari kombinasi berbagai dosis pupuk anorganik dengan biostimulan, mikoriza dan asam humat. Percobaan dilakukan di Kebun Percobaan Pusat Penelitian Perkebunan Gula Indonesia (P3GI) Pasuruan pada bulan Oktober 2018 sampai Oktober 2019. Perlakuan meliputi kombinasi berbagai dosis pupuk anorganik dengan biostimulan, mikoriza dan asam humat. Hasil penelitian menunjukkan bahwa semua perlakuan tidak berpengaruh nyata terhadap pertumbuhan, produksi tebu dan gula. Namun, pada perlakuan kombinasi pupuk anorganik sebesar $75 \%$ dari dosis optimal dengan asam humat memberikan produktivitas tebu sebesar 108,94 ton/ha dan gula sebesar 13,93 ton/ha, dan pada perlakuan kombinasi pupuk anorganik $100 \%$ dengan asam humat, mikoriza serta biostimulan yang diaplikasikan secara direndam maupun disemprot pada saat tanam, umur 1,5 bulan dan 3,5 bulan memberikan produktivitas tebu sebesar 112,67 ton/ha dan gula sebesar 14,13 ton/ha. Sementara, pada perlakuan standar (pupuk anorganik dosis 100\%) memberikan produktivitas tebu sebesar 100,05 ton/ha dan gula sebesar 13,31 ton/ha. Produktivitas tebu dan gula pada perlakuan kombinasi pupuk anorganik dengan mikoriza lebih rendah dari perlakuan pupuk anorganik standar yaitu sebesar 85,61 ton/ha dan 11,40 ton/ha.
\end{abstract}

Kata kunci: biostimulan, asam humat, mikoriza, pupuk anorganik, tebu

\section{ABSTRACT}

In achieving of sugar self-sufficiency, some efforts should be made to increase sugarcane productivity. One way that can be done is application of biostimulants, mycorrhizae and humic acid on sugarcane. The application of biostimulants, humic acid and mycorrhizae is expected to reduce the use of inorganic fertilizers. The aim of the study was to obtain the best treatment from the combination of various doses of inorganic fertilizers with 
biostimulants, mycorrhizae and humic acids. The experiment was conducted at the Indonesian Sugar Research Institute (ISRI) Pasuruan experimental station, from October 2018 to October 2019. The treatments included a combination of various doses of inorganic fertilizers with biostimulants, mycorrhizae and humic acids. The results showed that all treatments had no significant effect on growth, sugarcane and sugar production. However, in the combination treatment of inorganic fertilizers at $75 \%$ of the optimal dose with humic acid, the productivity of sugarcane was 108.94 tons/ha and sugar 13.93 tons/ha, and in the combination treatment of $100 \%$ inorganic fertilizers with humic acid, mycorrhizae and biostimulants that were applied by soaking or spraying at the time of planting, 1.5 months and 3.5 months old gave sugarcane productivity of 112.67 tons/ha and sugar 14.13 tons/ha. Meanwhile, the standard treatment (100\% dose of inorganic fertilizer) gave sugarcane productivity of 100.05 tons/ha and sugar 13.31 tons/ha. The productivity of sugarcane and sugar in the combination treatment of inorganic fertilizers with mycorrhizae was lower than the standard fertilizer treatment of 85.61 tons/ha and 11.40 tons/ha.

Keywords: biostimulants, humic acid, mycorrhizae, inorganic fertilizer, sugarcane

\section{PENDAHULUAN}

Produksi gula nasional sampai dengan tahun 2020 masih belum memberikan hasil yang memuaskan dengan hanya mencapai 2,13 juta ton atau turun $4,33 \%$ dibandingan tahun 2019 (Rahardja, 2020). Secara umum, produktivitas tebu dan rendemen tebu di Indonesia masih dikategorikan belum tinggi yaitu 70,72 ton/ha dan rendemen $7,00 \%$ (Anonim, 2020). Rendahnya produktivitas disebabkan salah satunya karena belum dilakukannya intensifikasi budidaya yang optimal. Upaya intensifikasi dapat dilakukan untuk meningkatkan produktivitas tebu dan gula, salah satunya melalui penggunaan biostimulan, asam humat dan mikoriza.

Biostimulan berfungsi untuk merangsang metabolisme tebu dengan meningkatkan pembentukan anakan, asimilat dan sintesa gula serta meningkatan bobot batang tebu. Biostimulan yang dapat digunakan adalah dari ekstrak bahan organik rumput laut dan telah digunakan pada pertumbuhan tebu di rumah kaca (Wahyuni et al., 2018). Hasil pengujian yang dilakukan menunjukkn bahwa dengan penggunaan biostimulan dapat memiliki bobot biomassa lebih berat dibandingkan kontrol (Putra et al., 2017).

Selain biostimulan, mikoriza telah banyak digunakan pada banyak komoditas untuk membantu pertumbuhan tanaman. Mikoriza telah dilaporkan terbukti sebagai agen hayati yang berfungsi untuk meningkatkan ketersediaan unsur hara dalam tanah. Akar yang berasosiasi dengan mikoriza dapat menyerap unsur hara dalam bentuk terikat dan yang menjadi tersedia bagi tanaman sehingga kebutuhan hara untuk menunjang pertambahan luas daun dapat terpenuhi dengan baik (Anas, 1997). Hasil penelitian Leovini et al. (2014) menujukkan dengan penggunaan mikoriza, bobot tebu menjadi lebih tinggi yang dikarenakan mikoriza lebih efektif dalam meningkatkan penyerapan unsur hara baik makro maupun mikro.

Asam humat juga salah satu alternatif bahan dalam meningkatkan performa tanaman. Asam humat merupakan dekomposisi dari bahan organik yang relatif resisten dan bersifat koloid (Mollah et al., 2020). Pengaruh tidak langsung dari pemberian asam humat adalah meningkatkan kualitas tanah sehingga penyerapan 
unsur hara meningkat, peningkatan respirasi akar, sintesis protein dan asam nukleat serta meningkatkan laju fotosintesis tanaman (Piccolo et al., 1992). Asam humat sebagai polimer alami tersedia banyak di alam (Yang and Antonietti, 2020).

Penggunaan biostimulan, asam humat dan mikoriza diharapkan dapat meningkatkan performa tanaman dan dapat mengurangi penggunaan pupuk anorganik. Oleh karena itu, percobaan dilakukan dengan mengombinasikan beberapa dosis pupuk anorganik. Percobaan dilakukan pada tanah Eutropepts di Pasuruan. Tanah Eutropepst memiliki karakteristik kandungan liat yang tinggi sehingga mempunyai kemampuan menahan air yang tinggi. Namun juga memiliki kelemahan cenderung memiliki drainase buruk. Tujuan dari penelitian adalah untuk mendapatkan perlakuan terbaik dari penggunaan biostimulan, mikoriza, asam humat dengan mengombinasikan beberapa dosis pemupukan.

\section{METODE}

\section{Waktu dan tempat}

Percobaan dilakukan mulai bulan September 2018 hingga September 2019. Tanam percobaan dilakukan di kebun tebu di Kelurahan Bakalan, Kecamatan Bugul Kidul, Kota Pasuruan yang memiliki karakteristik tanah dengan jenis Eutropepts bertekstur halus, drainase kurang lancar, dengan vegetasi lingkungan sekitar diluar kebun percobaan berupa area tebu dan persawahan. Ketinggian tempat \pm 4 mdpl dengan slope $<2 \%$. Daerah tersebut memiliki distribusi suhu maksimal $32^{\circ} \mathrm{C}$ dan suhu minimal $23^{\circ} \mathrm{C}$. Secara umum, kondisi kimia tanah di wilayah hamparan memiliki KTK 25-40 me/100 gr, pH 5,1-5,5. Selama kegiatan percobaan dilakukan (sejak tanam hingga panen), wilayah kajian memiliki curah hujan sebesar $1.299 \mathrm{~mm}$, dengan sebaran sebagaimana Gambar 1.

Pada Gambar 1 menunjukkan bahwa penanaman tebu dilaksanakan pada musim kemarau, namun pada saat penanaman, pengairan dapat dilakukan. Pada bulan berikutnya sampai dengan bulan Juni 2019 tanaman mendapatkan air dari hujan. Tanaman tebu berada pada bulan kering Agustus sampai dengan Oktober 2019 pada saat fase kemasakan sehingga kondisi ini mendukung kemasakan tebu.

\section{Alat dan bahan}

Bahan yang digunakan dalam percobaan adalah varietas tebu Bululawang, pupuk anorganik ZA, SP 36, biostimulan, asam humat dan mikoriza. Biostimulan, asam humat dan mikoriza diperoleh dari Pusat Penelitan Bioteknologi dan Bioindustri Indonesia (PPBBI), Bogor.

Biostimulan yang digunakan pada percobaan ini mengandung hara mikro $(\mathrm{Zn}$, $\mathrm{B}$ dan $\mathrm{Cu}$ ) fitohormon, hara makro $\left(\mathrm{P}_{2} \mathrm{O}_{5}\right.$, $\mathrm{K}_{2} \mathrm{O}$, dan $\mathrm{MgO}$ ) antioksidan, vitamin dan activator yang berbentuk cair. Asam humat yang digunakan minimal mengandung asam humat 9\% dalam bentuk cair. Sementara jamur mikoriza yang digunakan merupakan gabungan dari Azotobacter sp., Pseudomonas sp. dan Serratia mercescens dan memiliki 5 spora/gram dengan infeksi > 65\%. Lahan percobaan memiliki panjang juring $6 \mathrm{~m}$, dengan jarak Pusat ke Pusat (PKP) $1 \mathrm{~m}$. Rancangan percobaan yang digunakan adalah rancangan acak kelompok (RAK). Setiap plot percobaan terdiri dari 10 juring dengan jumlah ulangan sebanyak 3 kali. Luas total perlakuan dengan kelambu sekitar 0,4 ha. Total perlakuan percobaan sebanyak 12 perlakuan seperti pada Tabel 1 . 
Puspitasari \& Lukito: Pengaruh Biostimulan, Asam Humat, Mikoriza dan Kombinasi Dosis Pemupukan

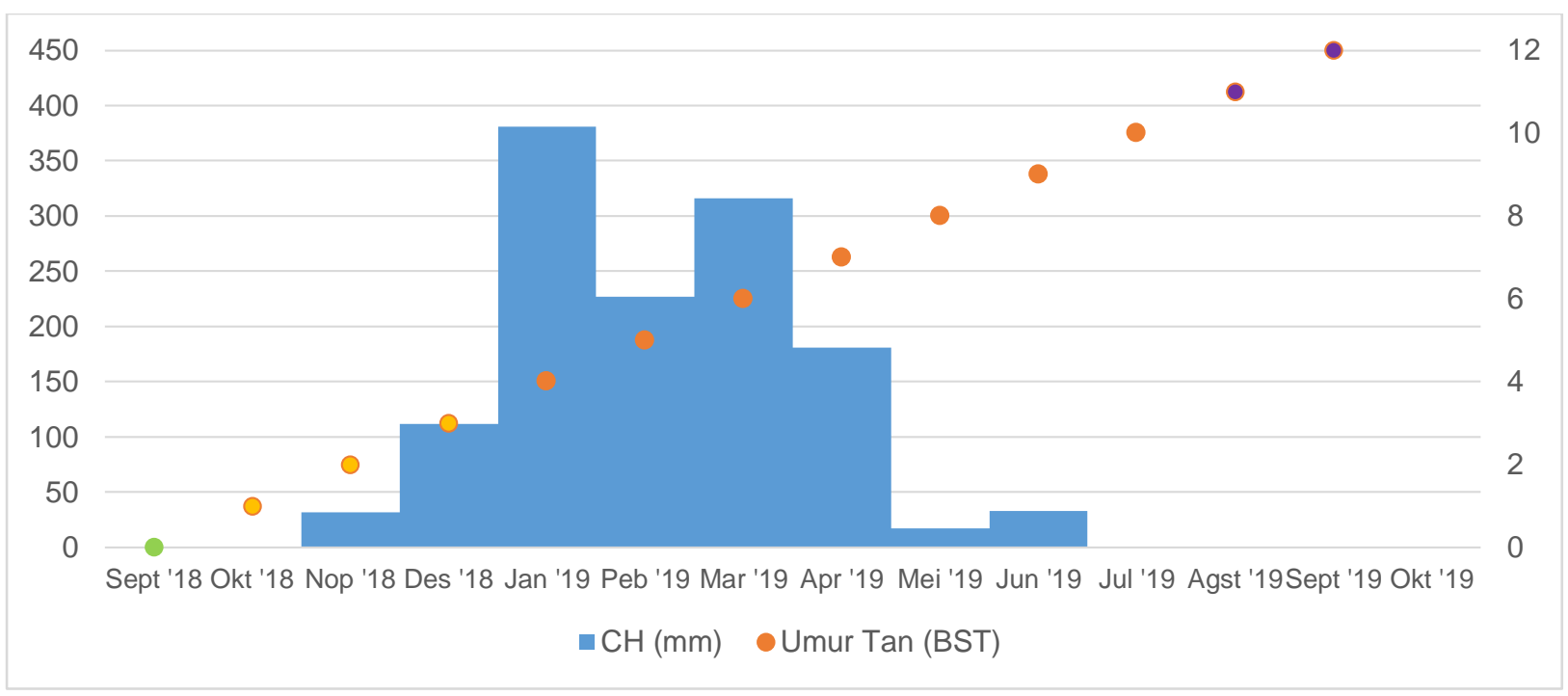

Gambar 1. Distribusi curah hujan selama kegiatan percobaan

Figure 1. Rainfall distribution during trial activity

Tabel 1. Perlakuan percobaan biostimulan, asam humat, mikoriza dan dosis pemupukan anorganik

Table 1. Biostimulant, humic acid, mikhorrizae and inorganik fertilizer dosage on experiment treatment

\begin{tabular}{cccccc}
\hline $\begin{array}{c}\text { Perlakuan } \\
\text { (Treatment) }\end{array}$ & $\begin{array}{c}\text { Biostimulan } \\
\text { rendam } \\
\text { (Biostimulants } \\
\text { soak) }\end{array}$ & $\begin{array}{c}\text { Biostimulan } \\
\text { semprot } \\
\text { (Biostimulants } \\
\text { spray) }\end{array}$ & $\begin{array}{c}\text { Asam humat } \\
\text { (Humic } \\
\text { acid) }\end{array}$ & $\begin{array}{c}\text { Mikoriza } \\
\text { (Mychorrizae) }\end{array}$ & $\begin{array}{c}\text { Dosis Pupuk } \\
\text { Anorganik } \\
\text { (Inorganic } \\
\text { Fertilizer } \\
\text { dosage) }\end{array}$ \\
\hline 1 & - & - & - & - & - \\
2 & - & - & - & - & $100 \%$ \\
3 & - & - & + & - & $75 \%$ \\
4 & - & - & - & + & $75 \%$ \\
5 & - & +++ & + & - & $100 \%$ \\
6 & - & +++ & + & + & $50 \%$ \\
7 & - & +++ & + & + & $100 \%$ \\
8 & + & ++ & + & & $100 \%$ \\
\hline
\end{tabular}

Keterangan: + : perlakuan 1 kali pd saat tanam; ++ : perlakuan 2 kali pada umur tanaman 1,5 bln; +++ : Perlakuan 3 kali pada umur tanaman 3,5 bulan, - : tidak ada perlakuan

Note: + : treatment 1 times; ++ : treatment 2 times; $+++:$ treatment 3 times; - : no treatment

\section{Prosedur pelaksanaan penelitian}

Biostimulan diberikan menggunakan dua cara yaitu melalui penyemprotan dan perendaman. Penyemprotan dilakukan pada umur 1,5 bulan dan 3,5 bulan. Sementara pada perendaman hanya dilakukan pada perendaman benih, sebelum tanam. Dosis penyemprotan maupun perendaman dengan biostimulan per ha yaitu $250 \mathrm{ml}$ biostimulan dan dilarutkan dalam 250 liter air. 
Penyemprotan biostimulan dilakukan pada daun tanaman. Pada perlakuan pembenah tanah asam humat, dosis yang diberikan adalah 6 liter per ha untuk melapisi (coating) pupuk anorganik. Pupuk hayati Mikoriza diberikan dengan dosis $50 \mathrm{~kg}$ per ha dan diberikan sebelum aplikasi pupuk anorganik. Dosis pupuk anorganik standar per ha adalah $800 \mathrm{~kg}$ ZA dan $200 \mathrm{~kg}$ SP 36. Pupuk ZA diberikan dalam dua kali aplikasi yaitu 1 minggu setelah tanam dan pada umur 2 bulan, sedangkan pupuk SP 36 diberikan sekaligus saat tanam, dimana perlakuan tersebut dianggap sebagai perlakuan $100 \%$. Pada kombinasi perlakuan, diberikan dosis pupuk 100\%, 75\% dan 50\% dari dosis standar.

\section{Variabel pengamatan}

Variabel pertumbuhan yang diamati adalah persen perkecambahan benih pada umur 1 bulan; jumlah rumpun, jumlah tunas per meter juring dan tinggi batang pada umur 3 bulan; jumlah batang per meter, tinggi batang dan diameter batang pada umur 6 dan 9 bulan, serta produktivitas tebu, rendemen maupun produktivitas gula per ha pada umur 12 bulan.

\section{Analisis Data}

Analisis statistik yang digunakan adalah Analisis of Varians (ANOVA) menggunakan program DSAASTAT dan uji lanjut menggunakan uji Beda Nyata Terkecil (BNT) 5\%.

\section{HASIL DAN PEMBAHASAN}

\section{Perkecambahan Benih Tebu}

Hasil pengamatan perkecambahan menunjukkan bahwa persen perkecambahan pada semua perlakuan berkisar antara 6779\% (Gambar 2). Gambar 2 menunjukkan tidak ada beda nyata pada semua perlakuan. Persen perkecambahan terendah terjadi pada perlakuan tanpa pemupukan dan tertinggi pada perlakuan 6 yaitu dengan penyemprotan biostimulan pada benih, penyemprotan umur 1,5 bulan, penyemprotan umur 3,5 bulan, aplikasi asam humat dan mikoriza serta penggunaan pupuk anorganik $50 \%$. Perkecambahan lebih banyak dipengaruhi oleh faktor kualitas benih yaitu umur yang tepat dan kesehatan benih.

Menurut Hanjokrowati (1981), faktor penting dalam perkecambahan tanaman tebu meliputi faktor eksternal yaitu pengelolaan kebun, pemilihan tempat, hama dan penyakit dan perlakuan benih. Sedangkan faktor internal yaitu kualitas bibit, kandungan glukosa, kandungan nitrogen dan air. Kondisi percobaan belum tampak adanya beda nyata, dimungkinkan karena kondisi benih yang sama, sehingga kandungan gula sebagai energi untuk berkecambah sama. Hal ini sesuai dengan penelitian Suyitno (2006) yang menyatakan bahwa zat sumber energi tidak selalu siap dalam bentuk glukosa, melainkan masih dalam bentuk cadangan makanan, yaitu berupa sukrosa atau amilum yang harus terlebih dahulu di bongkar secara hidrolitik. 


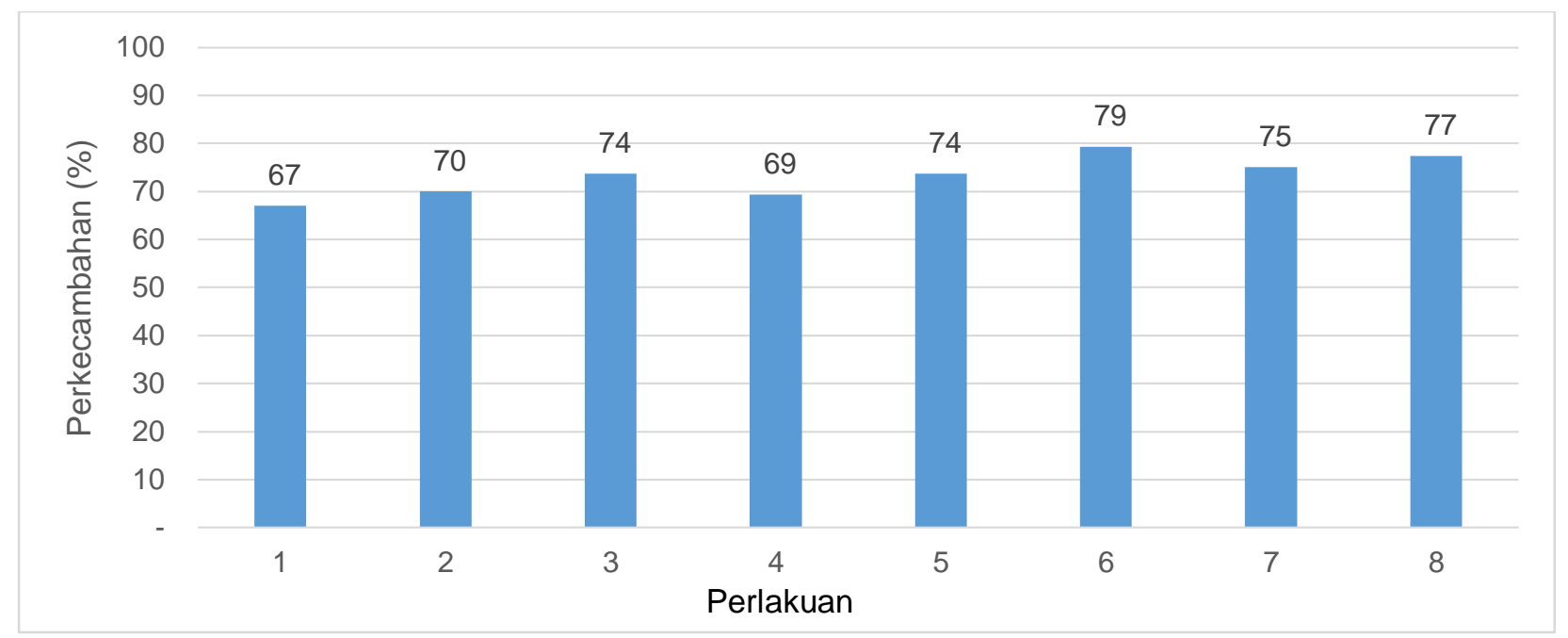

Gambar 2. Perkecambahan (\%) benih umur 1 bulan

Figure 2. Seed germination (\%) on 1 month old

Keterangan (note) :

$1=$ tanpa pemupukan (without fertilizer); 2 = pupuk anorganik $100 \%$ (100\% inorganic fertilizer); 3 = Pupuk anorganik $75 \%+$ asam humat (100\% inorganic fertilizer + humic acid); 4 $=$ Pupuk anorganik 75\% + mikoriza (75\% inorganic fertilizer + mychorrhizae) $; 5=$ Pupuk anorganik $100 \%+$ biostimulan 3 kali semprot (100\% inorganic fertilizer +3 times sprayed with biostimulants); 6 = Pupuk anorganik $50 \%+$ biostimulan 3 kali semprot + asam humat + mikoriza (50\% inorganic fertilizer +3 times sprayed with biostimulants + humic acid + mychorrhizae); 7 = Pupuk anorganik $100 \%+$ biostimulan 3 kali semprot + asam humat + mikoriza (100\% inorganic fertilizer +3 times sprayed with biostimulants + humic acid + mychorhizae); 8 = Pupuk anorganik 100\% + biostimulan 3 kali (rendam + semprot) + asam humat + mikoriza (100\% inorganic fertilizer +3 times dipping and sprayed with biostimulants + humic acid + mychorrhizae)

Kondisi tanah eutropepts yang sedang berkembang dengan tekstur halus didominasi pori-pori berukuran kecil. Air dan udara akan menempati ruang pori tersebut. Nutrisi serta air berpotensi diikat dalam pori tanah sehingga dampak pertumbuhan pada fase perkecambahan tidak signifikan terlihat perbedaannya.

\section{Keragaan Tanaman}

Hasil pengamatan umur 3 bulan (Tabel 2) menunjukkan tidak beda nyata antar perlakuan pada jumlah rumpun, jumlah tunas per meter dan tinggi batang. Jumlah rumpun yang tumbuh sekitar 27-32 rumpun per juring, jumlah tunas per $\mathrm{m}$ berkisar 11-18 tunas dan tinggi batang bervariasi dari $65-81 \mathrm{~cm}$. Tanaman tebu umur 3 bulan merupakan fase pertunasan tebu. Menurut Pawirosemadi (2011), faktor eksternal yang berpengaruh terhadap jumlah tunas adalah sinar matahari, dimana erat kaitannya dengan kandungan hormon dalam jaringan tanaman. Intensitas cahaya yang tinggi menyebabkan jaringan tanaman langsung menerima jerapan cahaya matahari, kandungan IAA juga akan menurun karena degradasi oksidasi. Adanya biostimulan, asam humat dan mikoriza belum menunjukkan pengaruh yang nyata terhadap jumlah rumpun, jumlah tunas dan tinggi batang dimungkinkan karena kondisi eksternal yaitu lingkungan tumbuh serta 
sinar matahari lebih dominan memicu pertumbuhan.

Pada Tabel 2 menunjukkan bahwa jumlah batang umur 6 dan 9 bulan tidak beda nyata pada semua perlakuan. Seiring dengan bertambahnya umur, terdapat penurunan jumlah batang antara $7 \%$ sampai dengan 17\%. Perlakuan 6 dan 8 memiliki penurunan jumlah batang lebih kecil dibanding perlakuan lainnya yaitu $7 \%$ dan 8\% (Gambar 3). Namun jika diperhatikan jumlah batang perlakuan 3 dan 8 memiliki kecenderungan jumlah batang lebih tinggi dibanding perlakuan lainnya. Sebagian besar jumlah batang mengalami puncaknya pada umur 2 sampai 3 bulan dan mengalami penurunan sampai dengan panen (Vasantha et al., 2012).

Tabel 2. Jumlah rumpun, jumlah tunas per $m$ dan tinggi batang umur 3 bulan

Table 2. Number of clump, number of tiller per $m$ and stalk height at 3 month old

\begin{tabular}{cccc}
\hline $\begin{array}{c}\text { Perlakuan } \\
\text { (Treatment) }\end{array}$ & $\begin{array}{c}\text { Jumlah rumpun } \\
\text { per juring (Number of clump } \\
\text { per row) }\end{array}$ & $\begin{array}{c}\text { Jumlah tunas per } \\
\text { meter (Number of } \\
\text { tiller per meter) }\end{array}$ & $\begin{array}{c}\text { Tinggi batang, cm } \\
\text { (Stalk height, cm) }\end{array}$ \\
\hline 1 & $29 \mathrm{~ns}$ & $11 \mathrm{~ns}$ & $65 \mathrm{~ns}$ \\
2 & $27 \mathrm{~ns}$ & $14 \mathrm{~ns}$ & $71 \mathrm{~ns}$ \\
3 & $32 \mathrm{~ns}$ & $18 \mathrm{~ns}$ & $75 \mathrm{~ns}$ \\
4 & $27 \mathrm{~ns}$ & $14 \mathrm{~ns}$ & $67 \mathrm{~ns}$ \\
5 & $30 \mathrm{~ns}$ & $15 \mathrm{~ns}$ & $67 \mathrm{~ns}$ \\
6 & $30 \mathrm{~ns}$ & $16 \mathrm{~ns}$ & $69 \mathrm{~ns}$ \\
7 & $30 \mathrm{~ns}$ & $17 \mathrm{~ns}$ & $77 \mathrm{~ns}$ \\
8 & $32 \mathrm{~ns}$ & $17 \mathrm{~ns}$ & $81 \mathrm{~ns}$ \\
\hline
\end{tabular}

Keterangan: Angka pada kolom yang mempunyai notasi huruf yang berbeda menyatakan beda nyata pada uji $\mathrm{BNT}(\alpha=0,05 \%)$

Note: The numbers followed by the same superscript letter showed no significant different based on the $L S D$ test $(\alpha=0,05 \%)$

Keterangan (note) :

1 = tanpa pemupukan (without fertilizer); 2 = pupuk anorganik 100\% (100\% inorganic fertilizer); 3 = Pupuk anorganik 75\% + asam humat (100\% inorganic fertilizer + humic acid); 4 $=$ Pupuk anorganik 75\% + mikoriza (75\% inorganic fertilizer + mychorrhizae $) ; 5=$ Pupuk anorganik $100 \%+$ biostimulan 3 kali semprot (100\% inorganic fertilizer +3 times sprayed with biostimulants); 6 = Pupuk anorganik $50 \%+$ biostimulan 3 kali semprot + asam humat + mikoriza (50\% inorganic fertilizer +3 times sprayed with biostimulants + humic acid + mychorrhizae); 7 = Pupuk anorganik 100\% + biostimulan 3 kali semprot + asam humat + mikoriza (100\% inorganic fertilizer +3 times sprayed with biostimulants + humic acid + mychorhizae); 8 = Pupuk anorganik 100\% + biostimulan 3 kali (rendam + semprot) + asam humat + mikoriza $(100 \%$ inorganic fertilizer +3 times dipping and sprayed with biostimulants + humic acid + mychorrhizae) 
Puspitasari \& Lukito: Pengaruh Biostimulan, Asam Humat, Mikoriza dan Kombinasi Dosis Pemupukan

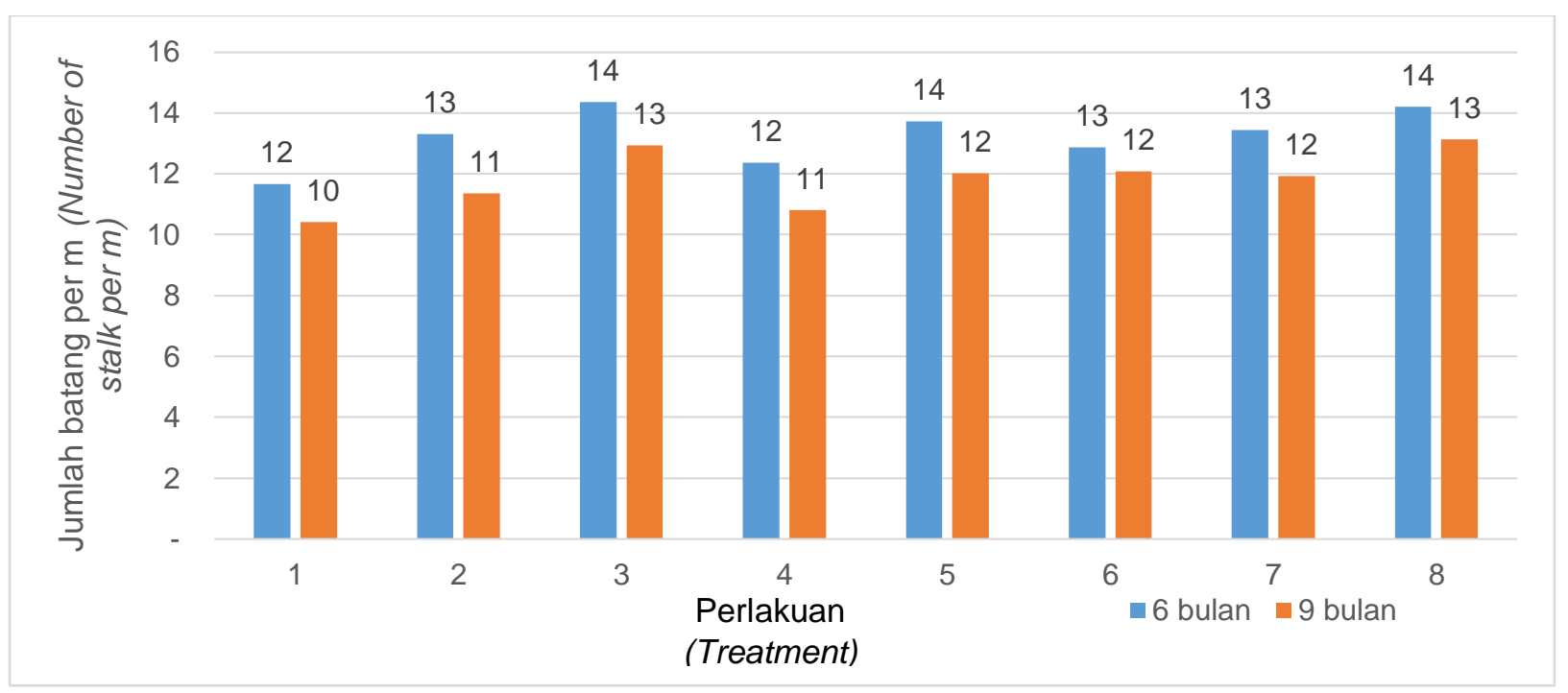

Gambar 3. Jumlah batang perlakuan biostimulan, asam humat, mikoriza dan dosis pemupukan pada umur 6 dan 9 bulan

Figure 3. Number of stalk on biostimulant, humic acid, mychorrhizae and fertilizer dosage treatment at 6 and 9 month old

Keterangan (note) :

1 = tanpa pemupukan (without fertilizer); 2 = pupuk anorganik 100\% (100\% inorganic fertilizer); 3 = Pupuk anorganik 75\% + asam humat (100\% inorganic fertilizer + humic acid); 4 $=$ Pupuk anorganik $75 \%+$ mikoriza (75\% inorganic fertilizer + mychorrhizae $) ; 5=$ Pupuk anorganik $100 \%+$ biostimulan 3 kali semprot $(100 \%$ inorganic fertilizer +3 times sprayed with biostimulants); 6 = Pupuk anorganik $50 \%$ + biostimulan 3 kali semprot + asam humat + mikoriza (50\% inorganic fertilizer +3 times sprayed with biostimulants + humic acid + mychorrhizae); 7 = Pupuk anorganik $100 \%+$ biostimulan 3 kali semprot + asam humat + mikoriza $(100 \%$ inorganic fertilizer +3 times sprayed with biostimulants + humic acid + mychorhizae); 8 = Pupuk anorganik 100\% + biostimulan 3 kali (rendam + semprot) + asam humat + mikoriza $(100 \%$ inorganic fertilizer +3 times dipping and sprayed with biostimulants + humic acid + mychorrhizae)

Hasil pengamatan tinggi batang, pada semua perlakuan tidak menunjukkan beda nyata pada umur 6 bulan maupun 9 bulan (lampiran 1 dan lampiran 2), namun semuanya mengalami peningkatan tinggi batang dari umur 6 ke 9 bulan (Gambar 4). Rata-rata peningkatan jumlah batang berkisar antara 20,36\%-33,35\%. Peningkatan tinggi batang terendah terjadi pada perlakuan 6 dan tertinggi pada perlakuan tanpa pemupukan. Namun demikian kecenderungan tinggi batang tertinggi terjadi pada perlakuan 3 dan 8 .
Hasil pengamatan pada parameter diameter batang, tidak terdapat beda nyata di antara perlakuan, namun terdapat peningkatan diameter batang dari umur 6 bulan ke 9 bulan dengan persentase 2,13\% $14,38 \%$. Peningkatan tertinggi terjadi pada pelakuan 1, 4 dan 8, tetapi diameter batang tertinggi terjadi pada perlakuan 3, 7 dan 8 . Peningkatan diameter batang lebih banyak dipengaruhi oleh kecukupan air.

Secara umum, pada umur 2 BST sudah mulai turun hujan hingga umur 8 BST, sehingga pertumbuhan anakan dan 
pemanjangan batang relatif optimum ditunjukkan dengan keragaannya. Hal ini mengakibatkan kecilnya pengaruh perlakuan terhadap pertumbuhan tinggi maupun diameter batang tanaman. Pada fase kemasakan, yakni 2 bulan sebelum panen, tanaman berada pada masa tanpa turunnya hujan (musim kering) sehingga kemasakan tebu diduga sudah optimal.

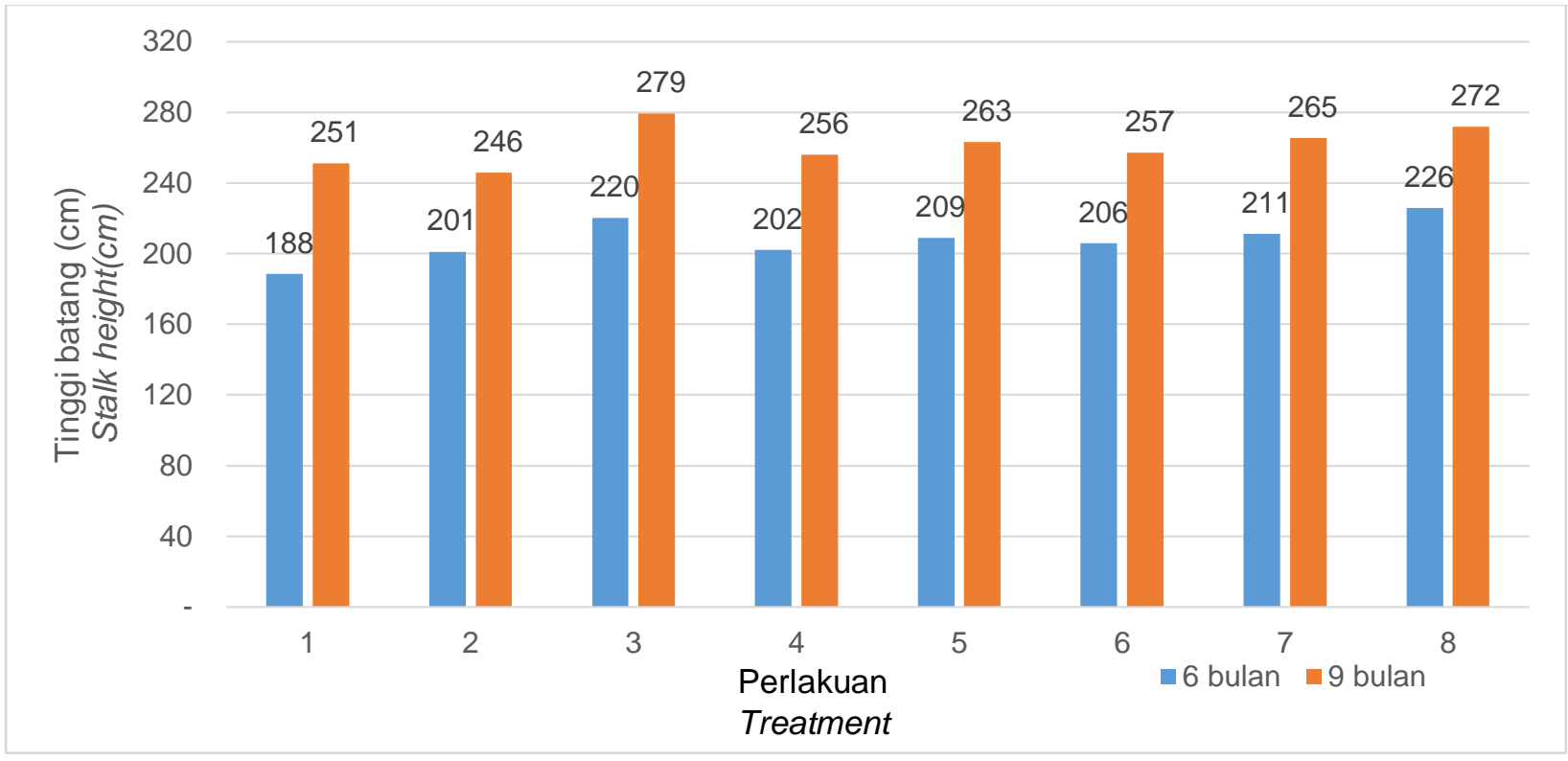

Gambar 4. Tinggi batang perlakuan biostimulan, asam humat, mikoriza dan dosis pemupukan pada umur 6 dan 9 bulan

Figure 4. Stalk height on biostimulant, humic acid, mycorrhizae and fertilizer dosage treatment at 6 and 9 month old

Keterangan (note) :

$1=$ tanpa pemupukan (without fertilizer) $; 2=$ pupuk anorganik $100 \%$ (100\% inorganic fertilizer); 3 = Pupuk anorganik $75 \%+$ asam humat $(100 \%$ inorganic fertilizer + humic acid $) ; 4$ $=$ Pupuk anorganik $75 \%+$ mikoriza $(75 \%$ inorganic fertilizer + mychorrhizae $) ; 5=$ Pupuk anorganik $100 \%+$ biostimulan 3 kali semprot $(100 \%$ inorganic fertilizer +3 times sprayed with biostimulants); 6 = Pupuk anorganik $50 \%+$ biostimulan 3 kali semprot + asam humat + mikoriza $(50 \%$ inorganic fertilizer +3 times sprayed with biostimulants + humic acid + mychorrhizae); 7 = Pupuk anorganik $100 \%+$ biostimulan 3 kali semprot + asam humat + mikoriza (100\% inorganic fertilizer +3 times sprayed with biostimulants + humic acid + mychorhizae); 8 = Pupuk anorganik 100\% + biostimulan 3 kali (rendam + semprot) + asam humat + mikoriza (100\% inorganic fertilizer +3 times dipping and sprayed with biostimulants + humic acid + mychorrhizae) 


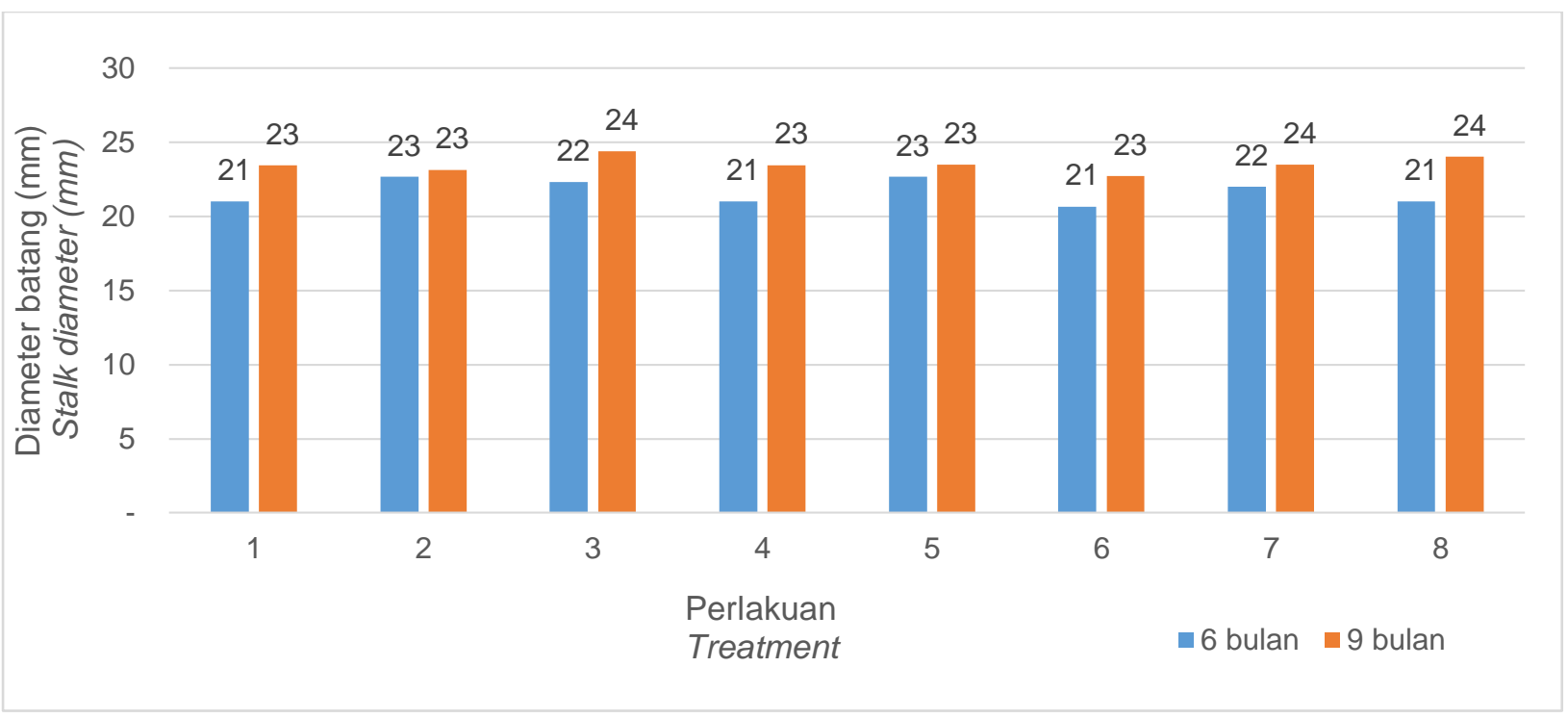

Gambar 5. Diameter batang perlakuan biostimulan, asam humat dan mikoriza pada umur 6 dan 9 bulan

Figure 5. Stalk diameter on biostimulant, humic acid, mycorrhizae and fertilizer dosage treatment at 6 and 9 month

Keterangan (note) :

1 = tanpa pemupukan (without fertilizer); 2 = pupuk anorganik $100 \%$ (100\% inorganic fertilizer); 3 = Pupuk anorganik 75\% + asam humat (100\% inorganic fertilizer + humic acid); 4 $=$ Pupuk anorganik $75 \%+$ mikoriza $(75 \%$ inorganic fertilizer + mychorrhizae $) ; 5=$ Pupuk anorganik $100 \%+$ biostimulan 3 kali semprot $(100 \%$ inorganic fertilizer +3 times sprayed with biostimulants); 6 = Pupuk anorganik $50 \%+$ biostimulan 3 kali semprot + asam humat + mikoriza $(50 \%$ inorganic fertilizer +3 times sprayed with biostimulants + humic acid + mychorrhizae); 7 = Pupuk anorganik $100 \%+$ biostimulan 3 kali semprot + asam humat + mikoriza (100\% inorganic fertilizer +3 times sprayed with biostimulants + humic acid + mychorhizae); 8 = Pupuk anorganik 100\% + biostimulan 3 kali (rendam + semprot) + asam humat + mikoriza $(100 \%$ inorganic fertilizer +3 times dipping and sprayed with biostimulants + humic acid + mychorrhizae)

\section{Produktivitas, Rendemen dan Hablur Gula}

Hasil pengamatan produktivitas tebu, diperoleh beda nyata antara perlakuan 2,3 , 5, 6 dan 8 terhadap perlakuan tanpa pemupukan (Tabel 3). Akan tetapi produktivitas tebu pada perlakuan kombinasi pupuk anorganik dengan biostimulan, asam humat dan mikoriza tidak beda nyata dengan produktivitas tebu pada perlakuan standar. Produktivitas tebu pada perlakuan 3 dan 8 lebih tinggi dari produktivitas tebu pada perlakuan standar berturut-turut sebesar 111,19 ton/ha dan 112,67 ton $\mathrm{ha}^{-1}$. Sementara rendemen tidak berbeda nyata pada semua perlakuan dengan kisaran 12,27\% - 12,33\%. Hasil hablur pada perlakuan kombinasi pupuk anorganik dengan biostimulan, asam humat dan mikoriza tidak berbeda nyata dengan hablur pada perlakuan standar (Tabel 3). Hablur gula terendah pada perlakuan tanpa pemupukan sebesar 7,93 ton ha ${ }^{-1}$, sedangkan hablur gula tertinggi pada perlakuan pupuk 
anorganik $75 \%$ + asam humat sebesar 14,53 ton $\mathrm{ha}^{-1}$. Bila dibandingkan dengan hablur gula perlakuan standar (hanya penggunaan pupuk anorganik dosis 100\%), terdapat peningkatan hablur gula sebesar $9,16 \%$ pada perlakuan pupuk anorganik $75 \%+$ asam humat, $6,17 \%$ pada perlakuan pupuk anorganik $100 \%+$ biostimulan 3 kali semprot, dan $4,60 \%$ pada perlakuan pupuk anorganik $100 \%+$ biostimulan 3 kali (rendam + semprot) + asam humat + mikoriza. Peningkatan produktivitas hablur dikarenakan peningkatan produktivitas tebu karena rendemen hampir sama di semua perlakuan baik yang dipupuk maupun tidak dipupuk. Pemberian mikoriza tidak menunjukkan pengaruh yang baik dimungkinkan karena kondisi lahan yang cukup air (lahan sawah). Sementara penambahan biostimulan dan asam humat pada perlakuan standar minimal $75 \%$ dosis pupuk anoganik memberikan kecenderungan hasil yang baik. Pemberian asam humat dalam mendukung pertumbuhan tanaman berhubungan dengan kandungan gugus carbolic (-COOH) dan phenolic ($\mathrm{OH}$ ) dalam asam humat (Salmin dan Ilahude, 1988). Muatan negatif dari gugus tersebut menjadikan asam humat efektif sebagai pengkelat hara makro, mikro dan molekul air sehingga mengurangi leaching, hal tersebut mampu meningkatkan ketersediaan dan pengambilan unsur hara untuk tanaman. Penggunaan biostimulan juga berfungsi untuk menambahkan hara makro dan mikro, hormon serta merangsang pertumbuhan vegetatif tanaman (Anonim, 2018).

Penyerapan hara oleh akar tanaman dapat melalui mekanisme intersepsi akar, aliran massa dan difusi (Munawar, 2011). Intersepsi hara oleh akar meningkat dengan adanya mikoriza, simbiosis antara jamur dan tanaman. Efek positif mikoriza ini paing besar bila tanaman tumbuh pada tanah-tanah yang kurang subur (Comerford 2005; Havlin et al., 2005). Hifa dari jamur meningkatkan luas permukaan bidang jerapan akar tanaman. Keberadaan mikoriza diharapkan mampu meningkatkan serapan air dan ketahanan terhadap kekeringan. Akan tetapi, dalam kondisi lingkungan di sekitar lokasi percobaan nampaknya kurang menunjukkan dampak tersebut, mengingat distribusi curah hujan dan waktu/ pola penanaman yang relatif sesuai untuk tebu sehingga kebutuhan serapan air masih tercukupi meskipun tanpa peran mikoriza. Diduga efek dari mikoriza akan menunjukkan hasil yang bervariasi untuk kondisi ragam tanah dan kondisi curah hujan yang berbeda pula. Coating pupuk yang dilakukan pada dosis yang lebih rendah dari kondisi kontrol (dosis 100\%) juga memiliki kecenderungan sama hasilnya, artinya reduksi pupuk standar dengan perlakuan coating pupuk akan memberikan nilai efektifitas pemupukan yang sama dari sisi hasil produksinya (perlakuan 3, 6, 7, 8). 
Tabel 3. Produktivitas tebu, rendemen dan hablur gula per ha

Table 3. Sugarcane yield, cane sugar content (CCS), and sugar productivity per ha

\begin{tabular}{|c|c|c|c|c|}
\hline $\begin{array}{c}\text { Perlakuan } \\
\text { (Treatment) }\end{array}$ & $\begin{array}{l}\text { Produktivitas } \\
\text { tebu }\left(\text { ton } \mathrm{ha}^{-1}\right) \\
\text { Sugarcane } \\
\text { productivity } \\
\left(\text { ton } \mathrm{ha}^{-1}\right)\end{array}$ & $\begin{array}{c}\text { Rendemen } \\
(\%) \\
C C S(\%)\end{array}$ & 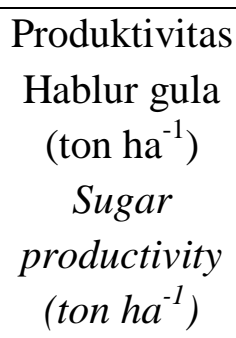 & $\begin{array}{l}\text { Peningkatan hablur }(\%) \\
\text { dibandingkan pupuk standar } \\
\text { (Sugar increase compared } \\
\text { to standard fertilization) }\end{array}$ \\
\hline 1 & $64.47 \quad \mathrm{a}$ & $12.32 \mathrm{~ns}$ & $7.93 \mathrm{a}$ & $-40,44$ \\
\hline 2 & $100.05 \mathrm{~b}$ & $13.32 \mathrm{~ns}$ & $13.31 \mathrm{~b}$ & 0,00 \\
\hline 3 & $111.19 \mathrm{~b}$ & $13,00 \mathrm{~ns}$ & $14.53 \mathrm{~b}$ & 9,16 \\
\hline 4 & $85.61 \mathrm{ab}$ & $13.33 \mathrm{~ns}$ & $11.40 \mathrm{ab}$ & $-14,37$ \\
\hline 5 & $108.84 \mathrm{~b}$ & $13.01 \mathrm{~ns}$ & $14.13 \mathrm{~b}$ & 6,17 \\
\hline 6 & $97.53 \mathrm{~b}$ & $12.44 \mathrm{~ns}$ & $12.13 \mathrm{~b}$ & $-8,92$ \\
\hline 7 & $89.00 \mathrm{ab}$ & $12.27 \mathrm{~ns}$ & $10.91 \mathrm{ab}$ & $-18,03$ \\
\hline 8 & $112.67 \mathrm{~b}$ & $12.38 \mathrm{~ns}$ & $13.93 \mathrm{~b}$ & 4,60 \\
\hline
\end{tabular}

Keterangan: Angka pada kolom yang mempunyai notasi huruf yang berbeda menyatakan beda nyata pada uji BNT $(\alpha=0,05 \%)$

Note: Different superscript letters indicated significant differences $(\alpha=0,05 \%)$

Keterangan (note) :

$1=$ tanpa pemupukan (without fertilizer); 2 = pupuk anorganik $100 \%$ (100\% inorganic fertilizer); 3 = Pupuk anorganik $75 \%+$ asam humat (100\% inorganic fertilizer + humic acid); 4 $=$ Pupuk anorganik $75 \%+$ mikoriza $(75 \%$ inorganic fertilizer + mychorrhizae $) ; 5=$ Pupuk anorganik $100 \%+$ biostimulan 3 kali semprot $(100 \%$ inorganic fertilizer +3 times sprayed with biostimulants); 6 = Pupuk anorganik $50 \%+$ biostimulan 3 kali semprot + asam humat + mikoriza $(50 \%$ inorganic fertilizer +3 times sprayed with biostimulants + humic acid + mychorrhizae); 7 = Pupuk anorganik 100\% + biostimulan 3 kali semprot + asam humat + mikoriza (100\% inorganic fertilizer +3 times sprayed with biostimulants + humic acid + mychorhizae); 8 = Pupuk anorganik 100\% + biostimulan 3 kali (rendam + semprot) + asam humat + mikoriza $(100 \%$ inorganic fertilizer +3 times dipping and sprayed with biostimulants + humic acid + mychorrhizae)

\section{KESIMPULAN}

Perlakuan penambahan biostimulan, asam humat dan mikoriza pada berbagai dosis pemupukan anorganik tidak memberikan pengaruh yang nyata terhadap pertumbuhan, hasil tebu dan rendemen. Namun, penambahan asam humat dan dosis pupuk anorganik $75 \%$, dan penambahan biostimulan sebanyak 3 kali baik disemprot maupun direndam dengan dosis pupuk anorganik 100\% memberikan hasil yang lebih baik dibandingkan hanya menggunakan pupuk anorganik 100\%. Terjadi peningkatan hablur gula sebesar $4,60 \%$ dengan penambahan asam humat pada dosis pupuk anorganik $75 \%$, dan $6,17 \%$ dengan penambahan biostimulan pada dosis pupuk anorganik $100 \%$. 


\section{DAFTAR PUSTAKA}

Anas, I. (1997). Bioteknologi tanah. Laboratorium biologi tanah. Institut Pertanian Bogor. Bogor.

Anonim. (2018). Sucrosin (Biostimulan untuk tanaman tebu). Pusat Penelitian Bioteknologi dan Bioindustri Indonesia. Bogor.

Anonim. (2020). Data Taksasi Akhir Giling Tahun 2020. Direktorat Jenderal Perkebunan. Jakarta. Tidaak Dipublikasikan.

Comerford, N. B. 2005. Soil factors affecting nutrient bioavailability. In: H. BassiriRad (Ed.). Nutrient Acquisition by Plants. An Ecological Prespective. Ecological Studies, Co.181. Springer-Verlag Berlin Heindelberg. pp:1-15

Hanjokrowati, ST. (1981). Teknik bercocok tanam tebu di lahan sawah. Lembaga Pendidikan Perkebunan. Yogyakarta. Hal. 1-12.

Havlin, J.L., Beaton, J.D., Nelson, S.L., Nelson, W.L. 2005. Soil Fertility and Fertilizers; An Introduction to Nutrient Management. Pearson Prentice Hall, New Jersey.

Leovini, H., Kastono, D. dan Widada, J. (2014). Pengaruh pemberian jamur mikoriza arbuscular, jenis pupuk fosfat dan takaran kompos terhadap pertumbuhan bibit tebu (Saccharum officinarum L.) pada media pasir pantai. Vegetalika 3(1): 102-115.

Mollah, A., Iswoyo, H. and Reskiana, N. (2020). Application of humic acid and guano on sugarcane seddlings with bud ste propagation method. ICROEST 2020. IOP Conf Series: Earth and Enviromental Sciences 575 (2020).

Munawar,A. 2011. Kesuburan Tanah dan Nutrisi Tanaman. PT Penerbit IPB Press.
Piccolo, A., Nardi, S. and Concheri, G. (1992). Structural characteristics of humic substances as related to nitrate uptake and growth regulation in plant systems. Soil Biol. Biochem. 24:373380.

Suyitno. (2006). Respirasi Pada Tumbuhan. Staf Pengajar Biologi FMIPA Universitas Negeri Yogyakarta. Yogyakarta.

Putra, S.M., Susanti, P., Amanah, D.M., Umahhati, B.K., Pardal, S.J. dan Santoso, D. (2017). Effects of biostimulats on vegetative growth of sugarcane variety PSJT 941. Menara Perkebunan, 85(1): 37-43.

Rahardja. W. (2020). Analisa hasil produksi GKP tahun giling 2020. Buletin AGI IKAGI, Edisi 5, Desember 2020. National Sugar Summit 2020.

Salmin dan Ilahude, A.G. (1988). Pencirian gugus-gugus asam humat berdasarkan analisis spektroskopi ultra lembayungcahaya tampak dan infra merah. Oseano 8(1):12-20.

Vasantha, S., Gupta, C., and Duraira, E. S.. (2012). Tiller production, regulation and senescence in sugarcane (Saccharum species hybrid) genotypes. Sugar Tech. DOI 10.11007/s12355-011-0129-6.

Wahyuni, S., Habibullah, H. S., Putra, S. M., Amanah, D. M., Siswanto, Priyono, Pardal, S. J dan Santoso, D. (2018). Biostimulasi pertumbuhan vegetatif tanaman tebu (Saccharum officinarum L.) pada fase awal di lahan kering. Menara Perkebunan 86(2):91-95.

Yang, F and Antonietti, M.. (2020). The sleeping giant : A polymer view on humic matter in synthesis and applications. Progress in Polymer Science.100:1 
Lampiran 1. Analisis ragam jumlah batang umur 6 bulan

Appendix 1. Analysis of variance on stalk number at 6 months

\begin{tabular}{|l|r|r|r|r|r|}
\hline \multicolumn{1}{|c|}{ ANOVA TABLE } & & & & \\
\hline \multicolumn{1}{|c|}{ EFFECT } & \multicolumn{1}{|c|}{ SS } & DF & MS & F & ProbF \\
\hline Blocks & 9.310908565 & 2 & 4.655454282 & 2.484401454 & \\
\hline Perlakuan & 17.48256655 & 7 & 2.497509507 & 1.332805753 & 0.305765 \\
\hline Residual & 26.23423032 & 14 & 1.873873595 & & \\
\hline Total & 53.02770544 & 23 & 2.30555241 & & \\
\hline C.V. $(\%): 10.3380560570929$ & & & & \\
\hline S.E.M.: 0.790331912253082 & & & & & \\
\hline S.E.D.: 1.11769810908457 & & & & \\
\hline LSD $(p<0.05): 2.39722402547549$ & & & & \\
\hline LSD $(p<0.01): 3.32721149524843$ & & & & \\
\hline
\end{tabular}

Lampiran 2. Analisis ragam jumlaah batang umur 9 bulan

Appendix 2. Analysis of variance on stalk number at 9 months

\begin{tabular}{|l|r|r|r|r|r|}
\hline \multicolumn{1}{|c|}{ ENFECT } & & & & \\
\hline \multicolumn{1}{|c|}{ ENO TABLE } & \multicolumn{1}{c|}{ SS } & DF & \multicolumn{1}{c|}{ MS } & F & ProbF \\
\hline Blocks & 8.720630787 & 2 & 4.360315394 & 2.825377162 & \\
\hline Perlakuan & 18.89749711 & 7 & 2.699642444 & 1.749301924 & 0.176697 \\
\hline Residual & 21.6057581 & 14 & 1.543268436 & & \\
\hline Total & 49.223886 & 23 & 2.140168956 & & \\
\hline C.V. $(\%): 10.4966309050625$ & & & & & \\
\hline S.E.M.: 0.717232746009826 & & & & & \\
\hline S.E.D.: 1.01432027678519 & & & & \\
\hline LSD $(p<0.05): 2.17550062693398$ & & & & \\
\hline LSD $(p<0.01): 3.01947194627302$ & & & & \\
\hline
\end{tabular}

